\title{
Lake Mweru and the Luapula Delta
}

\section{Author(s): A. Blair Watson}

Source: The Geographical Journal, Vol. 9, No. 1 (Jan., 1897), pp. 58-60

Published by: geographicalj

Stable URL: http://www.jstor.org/stable/1773644

Accessed: 27-06-2016 03:24 UTC

\section{Your use of the JSTOR archive indicates your acceptance of the Terms \& Conditions of Use, available at}

http://about.jstor.org/terms

JSTOR is a not-for-profit service that helps scholars, researchers, and students discover, use, and build upon a wide range of content in a trusted digital archive. We use information technology and tools to increase productivity and facilitate new forms of scholarship. For more information about JSTOR, please contact support@jstor.org.

The Royal Geographical Society (with the Institute of British Geographers), Wiley are collaborating with JSTOR to digitize, preserve and extend access to The Geographical Journal 
display which Mr. Craufurd was able to make, prevented a collision, although war-cries were raised and spears were flourished. Tribute was ultimately paid, and during a subsequent visit Mr. Craufurd had the satisfaction of receiving the submission of the sultan, "with tribute and every protestation of service and allegiance to her Gracious Majesty."

On December 4 he started homeward, first passing through extensive plantations of millet. He successively crossed Habala Afwa (open grass). and the Khumbi Bush, and reached the big lake, which had risen in the mean time, at Soyeh. On December 11 he was back at Kismayu.

Summing up his results, Mr. Craufurd states that the country as far as lat. $2^{\circ} \mathrm{N}$. presents the features of an undulating plain, covered with grass and thorn-bush. Acacias, mimosas, euphorbias, baobabs, and cactus form the regetation most noticeable, except near the Jub river, where wild date-trees, dum-palms, rushes, reeds, convolvulus, and other creepers abound. Many of the lakes seem to be merely ephemeral. The land presents all the features of an ancient sea-bottom.

The map accompanying this notice is copied from one forwarded by Mr. Crauford, but some information has been added from a map of the Jub prepared by Mr. R. J. Farrant.

\section{LAKE MWERU AND THE LUAPULA DELTA.}

By A. BLAIR WATSON, Collector of Revenue, Mweru District.

THE following account of further explorations by Mr. Blair Watson, whose visit to Kilwa island was described in the Journal for November, 1895, has been communicated to us by Sir Harry Johnston. Mr. Watson begins by describing a second visit to Kilwa, during which he more thoroughly explored the caves at the north-west end of the island than had been possible on the former occasion, when he had been much hampered by the want of a guide. He says-

"This time I took the old chief himself with me, and explored the caves thoroughly with him as guide. Last time I missed even the best. entrance. Passing through a small opening in a wall of rock, which rises at the water's edge a little in front of the cliff, one finds one's self in a cave formed by the overhanging cliff, and from the back of this a fine arched passage runs directly in for 60 or 70 yards, keeping much the same size throughout, 9 or 10 feet high, and about 7 feet wide. Offerings were made by the chief to the 'Mizimu' before we entered their particular chamber (the terminal one), and he was very much in earnest. over it. It was the first time that $I$ had seen any of the natives about. here take their Mizimu really seriously.

“From Kilwa I returned to Kafwimbe's, at the mouth of Chimbofuma, hitherto my outpost village on the south. Thence I came southwards to Kasamba, which lies at the south end of Chimbofuma. I am encamped 
here until the Mwitowa headman, whom I have placed here, has finished building his stockade. Under Kazembe this was an important place-his chief canoe port on the lake, from which its occupation cuts him off, except by the Luapula route, which Kilwa commands.

"On this journey I resumed my exploration of the Luapula, camping on the delta islands forming the south shore of the lake, and exploring from these the various channels entering its south end. On the east bank of the Luapula there are three principal places where the water leaves the main stream to pour over the delta flats at all seasons of the year. When the river is in flood, the banks are submerged for miles. The highest up and most important of these 'escapes' is a little below the point of entrance of the river Mlungusi. 'This runs to Mofwe lagoon, is fairly open, free from the grassy growth which covers much of the shallow waters of the delta, and affords at all times of the year free communication for canoes between this lagoon and the Luapula. The second is at Chisenga, about 17 miles up, and the third is about 5 miles. up at Pa-munga (so called from a dense mass of the thorny 'pith' tree, so common round Mweru shores). Escaping at these points, the waters. spread out to the eastward, being bounded by a steeply rising ridge which runs from Chimbofuma to the south end of Mofwe, forming the eastern bank of that lagoon. They are collected and pass into Mweru through four openings to the east of the principal mouth. These are, starting from the east, Chimbofuma, Chontontema, Kapulwe, and Mifimbo.

"The lagoon-like Chimbofuma is well known from Mr. Sharpe's map." It is about 6 miles long by 4 miles broad, and lies north and south. Its. south end is blocked by a dense grassy growth, which is encroaching on the open water. Boats can, however, still pass through this belt into the broad and deep Siki-mtu channel, leading to Chontontema, but in another year or two it will be impassable.

"Between Chimbofuma and Chontontema lies Sokwe island, with the Siki-mtu channel on the south. Chontontema is also lagoon-like, about 4 miles long by $1 \frac{1}{2}$ mile broad, narrowing at the mouth to about threequarters of a mile. Several side channels besides Siki-mtu open into it.

"Mwitowa island lies between Chontontema and the Kapulwe mouth. This is about 80 yards broad; its open water does not extend far now. Until lately these channels afforded free passage for canoes throughout the delta, and between Mofwe, the Luapula, and the lake. Of late years, however, the grass has encroached so much that the direct route from Mofwe to Mweru viâ Chimbofuma or Chontontema is now practically abandoned, and canoes pass into the Luapula by the channel entering nearly opposite the Mlungusi, and thence down the main stream. The mode of progression is by widely forked punting-poles, the fork of which allows considerable pressure to be exercised against the grass-stems.

* Geographical Journal, vol. i. p. 576 . 
Between the Kapulwe and Mifimbo mouths lies a small marshy island. Mifimbo opens about a mile west of Kapulwe; it affords a fairly direct passage into the Luapula at Pa-munga, and is still open enough for canoes to pass, and is still used.

"Sokwe island, nearly 6 miles long, is well raised above the lakelevel. It is well timbered, and much of it is covered with very dense bush. It was at one time inhabited and cultivated.

" Mwitowa island, 7 miles long, is generally well above water-level, though marshy in parts. It is also wooded, and has been inhabited. Both it and Sokwe abound in game-Puku, Lechwe, and Tragelaphus Spekei. Guinea-fowl are also present, and during this journey a leopard was seen by the men.

"To the west of the principal mouth of the Luapula there are two ehannels; the Kawongo mouth opens a little to the west of the main stream, and joins it less than a mile up. This is deep and open. The Kanantipa channel opens about a mile to the west of the principal mouth, and joins the main stream nearly opposite Pa-munga. Its Mweru extremity is now closed by grass. Immediately to the west of it, Kisumbu, a narrow rocky peninsula, stretches for a couple of miles north-north-east into the lake. The rock is sandstone, this and the Kilwa sedimentary rocks being probably part of the same formation. West of Kisumbu a broad shallow bay stretches away to the west coast of the lake.

"The country to the west of the lower course of the Luapula is occupied by a vast marsh, the Luongo Mbuga, which extends from the lake-shore almost to the Mlungusi. It is mostly dry in the dry season, but in the wet season is filled from the Luapula, which, when in flood, overflows its banks for miles. Some of the flood waters will thus make their way into the western arm of the lake; but no definite channel seems ever to have existed, and I could not hear that canoes were ever able to make their way into the river from this bay without passing round Kisumbu point.

"The water at the south end of Mweru, except opposite the main stream of the Luapula, is brown in colour, and unpleasant to the taste, from filtering through so much vegetation. The lake has risen very high this wet season, higher than for several years past.

"Several rivers flow into the delta. The Ngona, or Ngwena, on which Kazembe's town is situated, runs its own course in the dry season to the Luapula, which it enters a considerable distance above the Mlungusi. When in flood, however, it fills the swamp which extends between it and the south end of Mofwe, and thus some of its waters will pass into this lagoon ; there is no passage for canoes, however."

Mr. Watson concludes by referring to the beneficial effects which have resulted from the defeat of the chief Mlozi, and to the consequent insecure position of the Arabs settled in the We-usi country, where fighting with the natives has been going on for some time. 